\title{
Marie-Sainton syndrome (cleidocranial dysplasia): early diagnosis is the key
}

\author{
Sushmita Koduru Laxmi, ${ }^{1}$ Satya Ranjan Misra, ${ }^{1}$ Saurav Panda, ${ }^{2}$ Neeta Mohanty $\left({ }^{3}\right.$
}

${ }^{1}$ Oral Medicine and Radiology, Siksha O Anusandhan University Institute of Dental Sciences, Bhubaneswar, Odisha, India ${ }^{2}$ Periodontics, Siksha 0 Anusandhan University Institute of Dental Sciences, Bhubaneswar, Odisha, India ${ }^{3}$ Oral Maxillofacial Pathology and Microbiology, Siksha 0 Anusandhan University Institute of Dental Sciences, Bhubaneswar, Odisha, India

\section{Correspondence to}

Professor Neeta Mohanty; neetamohanty@soa.ac.in

Accepted 31 January 2022

\section{DESCRIPTION}

Marie-Sainton syndrome or cleidocranial dysplasia is a rare, autosomal dominant skeletal disorder (OMIM number 119600) caused by a mutation in the RUNX2 (CBFA1) gene encoding a runt-related transcription factor required in the differentiation of osteoblasts and chondrocytes. ${ }^{1}$ The affected patients have a short stature, skull deformity, mid-face hypoplasia, clavicular hypoplasia, delayed tooth eruption and multiple impacted supernumerary teeth. ${ }^{2}$ The skull abnormalities are characterised by patent fontanels or with delayed closure, open sutures and the presence of multiple Wormian bones. ${ }^{1}$ Root resorption is delayed in the primary dentition; hence there is retention of deciduous teeth. Root resorption is delayed, with a lack of cellular cementum, and the permanent teeth are impacted. There is pseudo-mandibular prognathism, non-union of symphysis menti in children, reduced facial height, high arched palate and malocclusion owing to a hypoplastic maxilla. ${ }^{3}$ Rarely even supernumerary teeth are not seen with this condition due to a missense mutation p.R131C (c.391C>T) in the RUNX2 gene. ${ }^{4}$ When the disorder is detected early, then the extraction of the retained deciduous teeth, along with surgical exposure and subsequent orthodontic movement of the permanent teeth, could be attempted, ensuring a better quality of life. $^{3}$

A 20-year-old female patient reported with the complaint of missing teeth. History revealed that her deciduous teeth did not exfoliate timely and her mother also suffered from a similar problem. On physical examination, short stature,

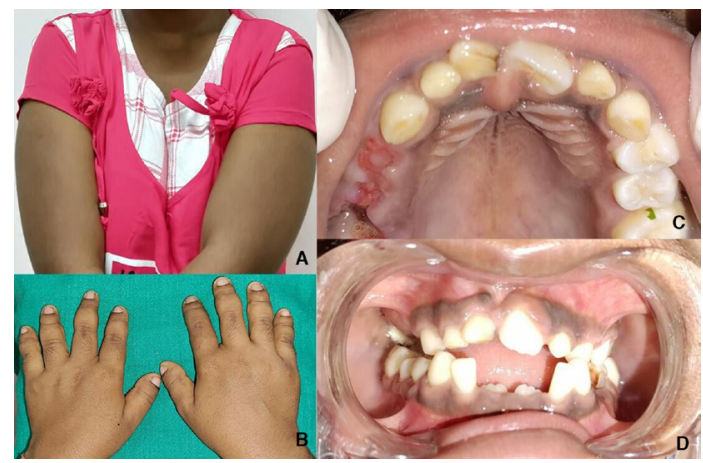

Figure 1 Clinical pictures showing shoulders approximating towards the midline, (A) Brachydactyly with wide thumb (B) and intraorally, multiple overretained deciduous teeth, missing permanent teeth and a high arched, narrow palate were seen $(C, D)$.

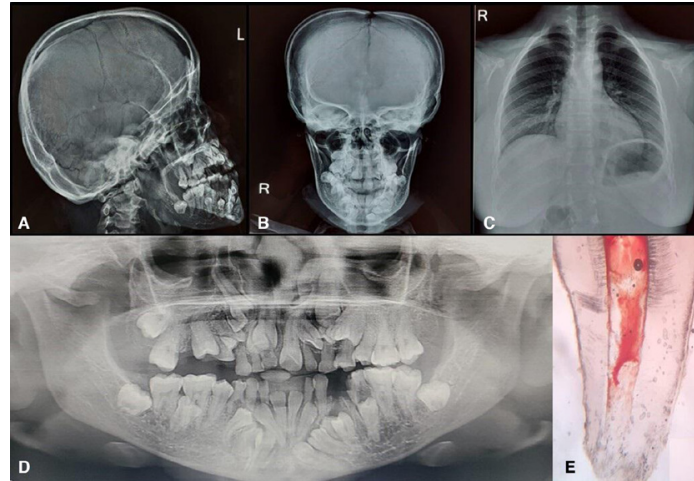

Figure 2 Skull radiographs showing widened cranial sutures with Wormian bones, frontal bossing and mid-face hypoplasia $(A, B)$, hypoplasia of the clavicles bilaterally on chest radiograph (C) and multiple impacted teeth, and over-retained deciduous teeth on panoramic radiograph (D). Ground section of deciduous tooth revealed absence of cellular cementum in the root $(\mathrm{E})$.

brachycephaly, frontal bossing, hypertelorism, depressed nasal bridge, limbs with hyperlaxity, shoulders appeared slanting and could be approximated towards the midline (figure 1A). Brachydactyly with wide thumbs (figure 1B), flat foot and genu valgo were also observed. Intraorally, multiple over-retained deciduous teeth, missing permanent teeth and a high arched, narrow palate were seen (figure 1C,D). The patient was subjected to radiological investigations. Widened cranial sutures with Wormian bones, frontal bossing and mid-face hypoplasia were seen on skull radiographs (figure 2A,B). Chest radiograph revealed hypoplasia of the clavicles bilaterally (figure 2C). Panoramic radiograph revealed multiple impacted teeth, impacted supernumerary teeth and over-retained deciduous teeth (figure 2D). The deciduous teeth

Learning points

- Marie-Sainton syndrome or cleidocranial dysplasia is an autosomal-dominant skeletal dysplasia affecting intramembranous ossification.

- The condition can be diagnosed from the clinicoradiological features like open fontanelles, hypoplastic clavicles and multiple supernumerary teeth.

- The management is multidisciplinary and requires long-term follow-up. 
were extracted, and ground section of the tooth revealed absence of cellular cementum in the apical third region of the root (figure 2E). The patient underwent extraction of deciduous teeth and was advised for orthodontic treatment.

Acknowledgements The authors thank Dr Swagatika Panda for the ground section of the tooth.

Contributors SP identified the patient; SRM and SKL diagnosed and investigated the patient; and NM prepared the manuscript.

Funding The authors have not declared a specific grant for this research from any funding agency in the public, commercial or not-for-profit sectors.

Competing interests None declared.

Patient consent for publication Consent obtained directly from patient(s).

Provenance and peer review Not commissioned; externally peer reviewed.
Case reports provide a valuable learning resource for the scientific community and can indicate areas of interest for future research. They should not be used in isolation to guide treatment choices or public health policy.

\section{ORCID iD}

Neeta Mohanty http://orcid.org/0000-0002-7449-3974

\section{REFERENCES}

1 Callea M, Bellacchio E, Fattori F, et al. Acute myeloid leukemia in a 3 years old child with cleidocranial dysplasia. Leuk Lymphoma 2016:57:2189-91.

2 Lotlikar PP, Creanga AG, Singer SR. Clinical and radiological findings in a severe case of cleidocranial dysplasia. BMJ Case Rep 2018;26:bcr2018226671.

3 Farrow E, Nicot R, Wiss A, et al. Cleidocranial dysplasia: a review of clinical, radiological, genetic implications and a guidelines proposal. J Craniofac Surg 2018;29:382-9.

4 Callea M, Fattori F, Yavuz I, et al. A new phenotypic variant in cleidocranial dysplasia (CCD) associated with mutation c.391C $>$ T of the RUNX2 gene. Case Reports 2012;2012:bcr1220115422.

Copyright 2022 BMJ Publishing Group. All rights reserved. For permission to reuse any of this content visit

https://www.bmj.com/company/products-services/rights-and-licensing/permissions/

BMJ Case Report Fellows may re-use this article for personal use and teaching without any further permission.

Become a Fellow of BMJ Case Reports today and you can:

- Submit as many cases as you like

- Enjoy fast sympathetic peer review and rapid publication of accepted articles

- Access all the published articles

Re-use any of the published material for personal use and teaching without further permission

\section{Customer Service}

If you have any further queries about your subscription, please contact our customer services team on +44 (0) 2071111105 or via email at support@bmj.com.

Visit casereports.bmj.com for more articles like this and to become a Fellow 